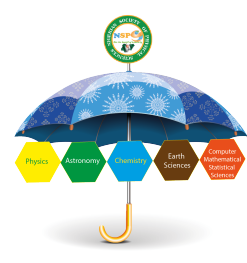

\title{
A Review of Evidence of Aerosol Transmission of SARS-CoV-2 Particles
}

\author{
S. S. Aladodo a,b,*, C. O. Akoshile ${ }^{\mathrm{b}}$, J. O. Otu ${ }^{\mathrm{a}}$ \\ ${ }^{a}$ Centre for Atmospheric Research Anyigba, Kogi State \\ ${ }^{b}$ University of Ilorin Ilorin, Nigeria
}

\begin{abstract}
Severe Acute Respiratory Syndrome Coronavirus 2 (SARS-CoV-2) causes Coronavirus disease (COVID-19) through multiple transmission routes and understanding the mode of transmission is very important for its containment and prevention. Consequently, inadequate attention has been given to the spread of respiratory droplets in indoor conditions under microclimatologic turbulent wind promoted by aerosol from talking (loud), coughing, sneezing, toilet flushing of an isolation room, and resuspension of the settled virus from the surfaces. To this end, this study is presenting the early review of the process and evidence of aerosol transmission of SARS-CoV-2 particles. There are significant results of many studies including those under peer review that support aerosol and airborne transmission which government agencies should consider for reducing the transmission rate.
\end{abstract}

DOI: $10.46481 /$ jnsps. 2021.162

Keywords: Aerosol transmission, SARS-CoV-2, Pandemic, Air recirculation, Respiratory droplet

Article History :

Received: 27 January 2021

Received in revised form: 17 June 2021

Accepted for publication: 19 July 2021

Published: 29 August 2021

(c)2021 Journal of the Nigerian Society of Physical Sciences. All rights reserved. Communicated by: O. J. Abimbola

\section{Introduction}

The second wave of the COVID-19 disease is already at the peak in some counties in Europe while gradually peaking up in some others such as Nigeria where some daily confirmed cases are above a thousand. The rate of spread of Coronavirus disease (COVID-19) caused by Severe Acute Respiratory Syndrome Coronavirus 2 (SARS-CoV-2) through the transportation of respiratory droplet, (aerosol) over a wide geographic area gives the reason to be declared a global public health emergency or pandemic by the World Health Organization (WHO) [1]. The hazards of the pandemic greatly increase morbidity

\footnotetext{
${ }^{*}$ Corresponding author tel. no: $+(234) 706924 x x x$

Email address: aladodoshehu@gmail .com (S. S. Aladodo)
}

and mortality globally and cause significant economic, social, and political disruption [2]. As of December 20th, 2020, the total confirmed cases of COVID-19 have exceeded 77 million nearly doubled the figure recorded as of October 2020 in 215 countries of the world with over 1.7 million mortality [3].

Nigeria has been one of the countries affected by the pandemic with over seventy-eight thousand $(78,000)$ cases recorded as of late December and over One thousand two hundred $(1,200)$ death cutting across the country. The first confirmed case in Nigeria was announced on 27 February 2020, when an Italian citizen in Lagos tested positive for the virus [4]. The multiple routes of transmission of COVID-19 disease such as respiratory droplet, contact, fomite, or air make it difficult to independently investigate each route of transmission. Evidence have shown 
that in addition to the mentioned modes of spread, transmission of SARS-CoV-2 through aerosol is imminent especially in closed indoor settings with poor ventilation and high probability of air recirculation $[3,4,5,6,7]$. This study aims to review the mechanism of aerosol suspension, transportation, deposition, and the evidence of aerosol transmission of COVID-19. Based on the established evidence of aerosol transmission, infection control methods were proposed to mitigate the aerosol transmission of the respiratory particles (SARS-CoV-2).

\section{Aerosol Sizes, Suspension, and Deposition}

The atmospheric aerosol is a suspension of fine solid and/or liquid matter which are either natural or emitted directly into the atmosphere by anthropogenic and biogenic sources or formed indirectly in the atmosphere by gas-to-particle conversion processes. It encompasses a wide range of particle types having different sizes, shapes, compositions, and optical properties [8]. Generally, its typical diameters range over four orders of magnitude, from a few nanometres to a few tens of micrometers otherwise referred to as aerodynamic diameter. Based on the size, aerosol can be classified into monodisperse (synthesized in the laboratory for experiment) and polydisperse which occur naturally with different sizes usually represented with a relative term particle size distribution. It has two distinct categories, fine and coarse particles. The fine particles are generally referred to as aerosols with diameters less than $2.5 \mu m$, while coarse particles are aerosols above $2.5 \mu \mathrm{m}$. These categories can be regrouped into modes. In the domain of coarse particles, there is usually only one mode which is called coarse mode and in the domain of fine particles are usually three modes: nucleation $(<20 \mathrm{~nm}$ in diameters), Aitken ( $\approx 20 \mathrm{~nm}$ to $\approx 100 \mathrm{~nm}$ in diameters $)$, and accumulation modes $(\approx 0.1 \mu m$ to $\approx 2 \mu m$ in diameters $)$ [8].

The Size and composition determine the ability of particles to serve as nuclei upon which other droplets in the atmosphere react and settled with. These aerosol processes involve different stages of formation, nucleation, condensation, and coagulation. During nucleation gas molecules or ultra-fine particles (nanoparticle- e.g. SARS-CoV-2) aggregate and can form a cluster that can condense into small liquid particles. This can be of the same molecules nucleating together (homogenous) or the nucleation happens on the surface of foreign particles (heterogeneous e.g. SAR-CoV-2 and Mouth Aerosol). When a lot of nucleated particles are formed and super saturation becomes low, condensation takes place instead of nucleation (Figure 1). At this point, there is no further formation of new particles. Instead, already existing particles start to grow. While coagulation occurs when two aerosol particles come in contact, collide and stick together. A collision can happen due to the Brownian motion of the particles in air, gravitational, phoretic, electrical, or other forces which all depend on the aerosol diameters. In the process, externally mixed particles become internally mixed and some small particles are lost due to the formation of larger particles, but the volume of particles is preserved [9].

Suspension of aerosol in the atmosphere greatly depends on aerosol type and modes of emission. The coarse mode aerosols are mechanically disintegrated parts of soils and their formation and emission greatly rely on the wind through the dragging of the particles on and off the surface (saltation) at a wind velocity referred to as erosion threshold velocity. For the anthropogenic aerosols that are directly emitted into the atmosphere due to human activities such as coughing, talking, sneezing as in the case of SARS-CoV-2 with the mouth aerosol. Once suspended in the atmosphere, many factors determine the residence time in the air such as physical properties, size, type, altitude range. The suspension period (Residence times) of aerosols vary significantly, from a few seconds for very large particles that soon after emission fall back on the ground, to years for sulphate aerosols stable at high altitudes in the stratosphere going through many phases during the cause of staying [10,11].

During the residence time, aerosol can be transported from emission sources to sink areas. Some of the aerosols e.g. desert dust can be transported over very long distances horizontally, commonly over several thousands of kilometers or more which have been proven by several studies with Sahara and Asian dust over the Atlantic ocean, Mediterranean sea, and other parts of the globe $[13,14,15]$. Some can be transported vertically in layer plumes into the stratosphere such as volcanic ash particles while others reside very close to the sources of emission such as sulphur dioxide $\left(\mathrm{SO}_{2}\right)$ [16]. The removal mechanism of the aerosol is what is refers as deposition, its mechanism is complex and depends on the locations and properties of the aerosol particles. It can be divided into dry and wet deposition. Dry deposition can either be deposition at the surface or gravitational sedimentation while wet deposition is in-cloud and below-cloud scavenging [17].

The dry deposition at the surface is an aerosol deposition process in which particles are removed from the atmosphere by the interaction with the surface, or more precisely with the atmospheric surface layer and a thin layer of air next to the surface (quasi-laminar sublayer). The dry deposition flux directly depends on the aerosol concentration:

$$
F_{d d}=v_{d d} \eta
$$

where $\eta$ is the aerosol concentration and $v_{d d}$ is the deposition velocity in $m s^{1}$. The deposition velocity depends on size, shape, the density of particles, properties of the surface, and the turbulence in the surface layer. The smallest particles in Aitken mode (e.g. SARS-CoV-2) are subjected to Brownian motion, collide with the surface and get deposited while the bigger size and coarse mode particles can be deposited through interception and impaction respectively [18]. Coarse mode particles can also be subjected to gravitational settling due to the gravitational force that makes the particles fall and because of their large sizes, and it makes their atmospheric lifetime very short. Wet removal mechanisms are processes that act on aerosols via atmospheric hydrometeors (cloud droplets, rain, snow, fog) and deposit them to the surface. Both in-cloud and below-cloud mechanisms can be efficient in aerosol removal and are reversible, because all hydrometeors that scavenged aerosols can also evaporate, releasing aerosols back into the air [17]. 


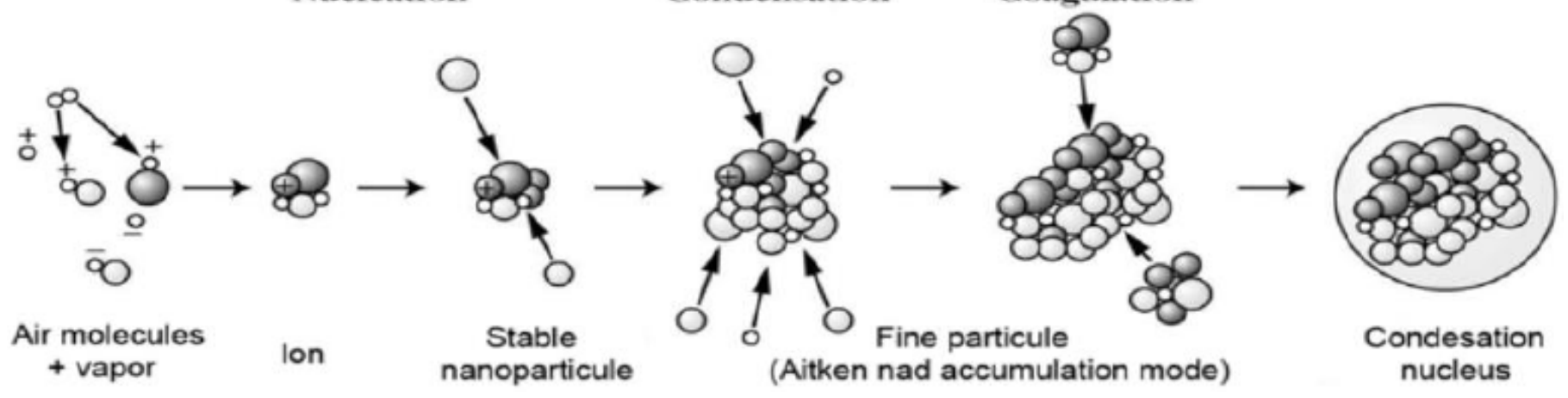

Figure 1. Possible Path of Evolution of a Particle, from Nucleation to Coagulation [12].

\section{Viral Aerosol Transmission}

It has been established by many studies that body fluids can be aerosolized through daily activities such as coughing, and medical procedures. Deposited particles can be aerosolized through re-suspension due to floor cleaning, and biological specimens can be aerosolized through improper laboratory procedures. In all, the infectious virus particles can be easily suspended in the atmosphere and as a result infect others [7 and some ref therein]. The suspended infectious aerosol particles (SARS-CoV-2) can now be transported as either homogenous nucleated, heterogeneous nucleated, condensed, or coagulated aerosols and later deposited on any surface by either dry or wet deposition or directly inhale with the fine aerosol in air. Experimental research has demonstrated the variety of respiratory viruses which includes the Middle East Respiratory Syndrome coronavirus (MERS-CoV), Severe Acute Respiratory Syndrome coronavirus (SARS-CoV), norovirus, and influenza virus could be transmitted by aerosols under certain conditions such as climatic and environmental [19, 20, 21, 22].

\section{Evidence of Aerosol Transmission of SARS-CoV-2}

According to Jones and Brosseau [23] there were three criteria set for aerosol transmission of the virus to be imminent (1) the mouth aerosol containing virus must be from an infectious person, (2) the virus must be able to exist and infective in aerosol for its residence time, and (3) the target tissues must be accessible to an aerosol with required viral load. Several studies have shown in the case of first criteria that SARS-CoV-2 particles are discharged into the atmosphere through respiratory droplets of infected person [3,4], and it has been frequently detected in the throat, conjunctival, and anal swabs. When a person coughs, talks or breathes, they throw in any direction between 900 to 300,000 liquid particles from their mouth which ranges in size, and a cough can send them traveling at speeds up to $60 \mathrm{mph}$ which keeps them suspended in the air for some time [24]. Since breathing and speaking occur more frequently than coughs and sneezes, they have a critical role in viral transmission, particularly from asymptomatic cases and bigger size droplet $(>50 \mu \mathrm{m}$ ) has a higher probability of containing the virus than smaller size droplet before dehydration
[25]. One minute of loud-speaking could produce thousands of oral droplets per second, of these at least 1000 virus-containing droplet nuclei could remain airborne for more than $8 \mathrm{~min}$ hence there are high chances of likelihood to be inhaled by others and thus trigger new infections [26].

The viability of the SARS-CoV-2 virus in aerosol according to the second criteria has been investigated experimentally by several authors. Van Doremalen et al. [27] demonstrated that SARS-CoV-2 can survive for more than three hours in the air under control conditions of temperature $21{ }^{\circ} \mathrm{C}-23{ }^{\circ} \mathrm{C}$ and relative humidity $65 \%$. Also, a UK variant of SARS-CoV-2 could remain viable in aerosols for at least $90 \mathrm{~min}$ under experimental conditions (artificial saliva and tissue culture media). Another investigation reveals that SARS-CoV-2 in respire-ablesized aerosols could persist and maintain infectivity for up to $16 h$ [28]. These are just a few in many studies pointing out the persistence and viability of coronavirus in aerosols. According to Song et al. [7] epidemiological studies are difficult to interpret concerning the role of transmission unless other routes can be ruled out. Different recent studies have investigated the role of air transmission of SARS-CoV-2 ruling out other routes such as Read [29], Shen et al. [30], and Lu et al. [31] and airborne route appeared to be a major contributor for the super spreading of the virus in an air recirculation environment. Some occurrences of COVID-19 disease across the globe where aerosol transmission might have played a role are tabulated in Table 1.

\section{Control and Elimination of Aerosol Transmission}

The main measure to curtain the aerosol transmission of infectious disease is ventilation. This promotes the air dilution around a source dispersing the aerosol, and the removal of respiratory viruses through Brownian motion in an open atmosphere $[36,37,38]$. The use of face masks which is recommended by the Nigeria Centre for Disease Control (NCDC) probably blocks some aerosol from leaving the mouth and reduces the chances of inhaling the aerosol contaminated with the virus in the air $[4,7,24]$. 
Table 1. Some of the Cases Indicating Possible Aerosol Transmission of SAR-CoV-2 Virus.

\begin{tabular}{|c|c|c|c|c|}
\hline & Place/Country & Date & $\begin{array}{l}\text { Findings } \\
\end{array}$ & Author(s) \\
\hline & Lab (USA) & $13 / 04 / 2020$ & $\begin{array}{l}\text { SAR-CoV-2 Particles remain infectious } \\
\text { in aerosol for up to sixteen hours. }\end{array}$ & Fears et al. [28] \\
\hline & Hospital (China) & 08/03/2020 & $\begin{array}{l}\text { Deposited samples in ICU and air samples } \\
\text { in makeshift hospital patient toilet were } \\
\text { positive for SAR-CoV-2 virus. }\end{array}$ & Liu et al. [32] \\
\hline Environment & Hospital (China) & 03/04/2020 & $\begin{array}{c}\text { Four surfaces out of one hundred and seven } \\
\text { surfaces in the hospital environment } \\
\text { sampled tested positive. }\end{array}$ & Ding et al. [33] \\
\hline \multirow{3}{*}{ Cases } & Outdoor air (Italy) & $15 / 04 / 2020$ & $\begin{array}{l}\text { SARS-CoV-2 RNA was detected on outdoor } \\
\text { particulate matter (PM) suggesting that, } \\
\text { in stable atmospheric condition and high } \\
\text { concentrations of PM, SARS-CoV-2 could } \\
\text { create clusters with outdoor PM. }\end{array}$ & Setti et al. [34] \\
\hline & Public Transport (USA) & $11 / 02 / 2020$ & $\begin{array}{c}\text { Two died and at least } 103 \text { people have } \\
\text { infection among } 1,111 \text { crew and 2,460 } \\
\text { passengers in the Grand Princess } \\
\text { cruise ship. }\end{array}$ & Moriarty et al. [35] \\
\hline & Restaurant (China) & $26 / 01 / 2020$ & $\begin{array}{l}\text { Aerosol transmission of an outbreak in a } \\
\text { restaurant in Guangzhou, China which is } \\
\text { explainable only to Air-conditioned } \\
\text { ventilation while the distance between } \\
\text { the occupant is greater than one meter. }\end{array}$ & Lu et al. [31] \\
\hline
\end{tabular}

\section{Conclusion}

Severe Acute Respiratory Syndrome Coronavirus 2 (SARS$\mathrm{CoV}-2$ ) particles have been established as an aerosol, based on their size, shape, and state. As an aerosol particle, it can nucleate, condense, and coagulate with either its type or other aerosol particles which can be suspended, transported, and deposited on various surfaces. Studies have shown with the significant number of evidence that SARS-CoV-2 is transmissible through the inhalation of infected aerosol particles present in the air most especially in air recirculated environments. The chain of transmission through aerosol could be broken with full ventilation of airtight environment and face masking.

\section{Acknowledgments}

We thank the referees for the positive enlightening comments and suggestions, which have greatly helped us in making improvements to this paper.

\section{References}

[1] J. Sun, W.-T. He, L. Wang, A. Lai, X. Ji, X. Zhai, G. Li, M. A. Suchard, J. Tian \& J. Zhou, "COVID-19: Epidemiology, evolution, and crossdisciplinary perspectives", Trends Mol. Med., (2020).

[2] N. Madhav, B. Oppenheim, M. Gallivan, P. Mulembakani, E. Rubin \& N. Wolfe, "Pandemics: Risks, impacts, andmitigation. In Disease Control Priorities: Improving Health and Reducing Poverty", Int. Bank Reconstr. Dev. Washington, DC, USA, (2017).

[3] WHO, World Heath Organization, "Coronavirus disease 2019 (COVID19) Situation Report", (2020).

[4] NCDC, Nigeria Centre for Disease Control, "First Case of Corona Virus Disease Confirmation in Nigeria", Press release February, (2020).
[5] CDC, Centre for Disease Control, "Interim Infection Prevention \& Control Recommendations for Patients with Suspected or Confirmed Coronavirus Disease 2019 (COVID-19) in Healthcare Settings", (2020).

[6] NHC, National Health Commission, "Diagnosis \& treatment plan of COVID-19 (trial version 7). (in Chinese)", (2020).

[7] T. Song, Y. Mao, R. M. Jones, Q. Tan, J. S. Ji, N. Li, J. Shen, Y. Lv, L. Pan, P. Ding, X. Wang, Y. Wang, C. R. Macintyre \& X. Shi, "Aerosol transmission of SARS-CoV-2? Evidence, prevention and control", Environment International, 144 (2020) 1, https://doi.org/doi.org/10.1016/j.envint.2020.106039.

[8] J. Seinfeld \& S. Pandis, "Atmospheric Chemistry and Physics: From Air Pollution to Climate Change" New York: John Wiley and Sons., (998).

[9] M. Z. Jacobson, "Fundamentals of atmospheric modeling", Cambridge University Press, (2005).

[10] P. Chazette, C. David, J. Lefrere, S. Godin, J. Pelon \& G. Mègie, "Comparative lidar study of the optical, geometrical, and dynamical properties of stratospheric post-volcanic aerosols, following the eruptions of El Chichon and mount Pinatubo", Journal of Geophysical Research: Atmospheres, 100 (1995) 23195.

[11] P. Chazette, F. Dulac, J. Sanak \& B. Johnson, "Vertical structure of aerosols and water vapor over West Africa during the African monsoon dry season", Atmospheric Chemistry and Physics, (2009) 8017.

[12] R. Delmas, G. Mègie \& V.-H. Peuch, "Physique et chimie de l'atmosphère", Belin (2005).

[13] T. Carlson \& J. Prospero, "The Large-Scale Movement of Saharan Air Outbreaks over the Northern Equatorial Atlantic", Journal of Applied Meteorology, 11 (1972) 283.

[14] J. M. Prospero, "Long-range transport of mineral dust in the global atmosphere: Impact of African dust on the environment of the southeastern United States", Proc. Natl. Acad. Sci. (1999) 3396.

[15] K. Uno, K. Eguchi, T. Yumimoto, A. Takemura, M. Shimizu, Z. Uematsu, Z. Liu, Y. H. Wang \& N. Sugimoto, "Asian dust transported one full circuit around the globe", Nature Geoscience 2 (2009) 557.

[16] C. Liousse, B. Guillaume, J. M. Gr \& S. Martin, "Updated African biomass burning emission inventories in the framework of the AMMAIDAF program, with an evaluation of combustion aerosols", (2010) 9631, https://doi.org/10.5194/acp-10-9631-2010.

[17] S. Bojan, "Improvement of aerosol representation in achemical-transport 
model: Modelling and data assimilation", $\mathrm{PhD}$ Thesis, University of Toulouse (2014).

[18] W. Slinn, "Predictions for particle deposition to vegetative canopies", Atmospheric Environment 16 (1988) 1785.

[19] M. Zietsman, L. T. Phan \& R. M. Jones, "Potential for occupational exposures to pathogens during bronchoscopy procedures". J. Occup. Environ. Hygiene 16 (2019) 707.

[20] D. Johnson, R. Lynch, C. Marshall, K. Mead \& D. Hirst, "Aerosol generation by modern flush toilets", Aerosol Sci. Technol.: J. Am. Assoc. Aerosol Res. 47 (2013) 1047.

[21] A. Mustaffa-Babjee, A. L. Ibrahim \& T. S. Khim, "A case of human infection with Newcastle disease virus. Southeast Asian”, J. Trop. Med. Public Health 7 (1976) 622.

[22] P. Khare \& L. C. Marr, "Simulation of vertical concentration gradient of influenza viruses in dust resuspended by walking", Indoor Air 25 (2015) 428.

[23] R. M. Jones \& L. M. Brosseau, "Aerosol transmission of infectious disease", J. Occup. Environ. Med. 57 (2015) 501.

[24] S. L. Miller, W. W. Nazaroff \& J. L. Jimenez, "Transmission of SARSCoV-2 by inhalation of respiratory aerosol in the Skagit Valley Chorale superspreading event", (2020), https://doi.org/2020.06.15.20132027.

[25] R. Wölfel, V. M. Corman \& W. Guggemos, "Virological assessment of hospitalized patients with COVID-2019”, Nature 581 (2020) 465.

[26] V. Stadnytskyi, C. E. Bax, A. Bax \& P. Anfinrud, "The airborne lifetime of small speech droplets and their potential importance in SARS-CoV-2 transmission", PNAS 117 (2020) 11875.

[27] T. van Doremalen, N. Bushmaker \& D. Morris, "Aerosol and surface stability of HCoV-19 (SARS-CoV-2) compared to SARS-CoV-1", medRxiv (2020), https://doi.org/2020.03.09. 20033217.

[28] A. C. Fears, P. Klimstra, William B. Duprex, H. Amy, S. C. Weaver, D. Plante, Kenneth S. Mirchandani, D. Plante, Jessica Ann, Aguilar, Patricia V. Fernández, A. Nalca, A. Totura, D. Dyer, R. Kearney, Brian Lacke- meyer, Matthew Bohannon, J. Kyle Johnson, R. F. Garry, D. S. Reed \& C. J. Roy, "Persistence of severe acute respiratory syndrome cor- onavirus 2 in aerosol suspensions", Emerg. Infect. Dis. 26 (2020), https://doi.org/10. 3201/eid2609.201806.

[29] R. Read, "A choir decided to go ahead with rehearsal. Now dozens of members have COVID-19 and two are dead", (2020), www.latimes.com/world-nation/story/2020-03-29/coronavirus-choiroutbreak.

[30] Y. Shen, C. Li \& H. Dong, "Airborne transmission of COVID-19: epidemiologic evidence from two outbreak investigations", ResearchGate, (2020).

[31] J. Lu, J. Gu \& K. Li, "COVID-19 outbreak associated with air conditioning in restaurant, Guangzhou, China”, Emerg. Infect. Dis. (2020) 1628.

[32] Y. Liu, Z. Ning \& Y. Chen, "Aerodynamic analysis of SARS-CoV-2 in two Wuhan hospitals", Nature 582 (2020) 557.

[33] Z. Ding, H. Qian \& B. Xu, "Toilets dominate environmental detection of SARS- CoV-2 virus in a hospital", medRxiv, (2020).

[34] L. Setti, F. Passarini \& G. De Gennaro, "SARS-Cov-2RNA found on particulate matter of Bergamo in Northern Italy: First evidence", Environ. Res. 188 (2020) 109754.

[35] L. F. Moriarty, M. M. Plucinski \& B. J. Marston, "Public health responses to COVID-19 outbreaks on cruise ships - worldwide, February-March 2020”, MMWR Morb. Mortal. Wkly Rep (Washington, D.C, 2020).

[36] P. W. Francisco \& S. J. Emmerich, "ASHRAE Position Document on Airborne Infectious Diseases", (Georgia, 2014).

[37] G. Rolph, A. Stein \& B. Stunder, "Real-time Environmental Applications and Display System: READY", Environmental Modelling and Software 95 (2017) 210, https://doi.org/10.1016/j.envsoft.2017.06.025.

[38] A. F. Stein, R. R. Draxler, G. D. Rolph, B. J. B. Stunder, M. D. Cohen \& F. Ngan, "NOAA's HYSPLIT atmospheric transport and dispersion modeling system", American Meteorological Society 96 (2015) 2059. 